- During the period of recovery, postoperative anxiety and pain experienced by young children who had extractions under general anaesthesia with preoperative analgesic suppositories were not affected by perioperative injection techniques of local anaesthesia.

- Perioperative intraligamental injection of local anaesthetic appears beneficial as it results in lower postoperative pain scores on the first night postoperatively.

- The use of preoperative analgesic suppository with perioperative local anaesthetic remains beneficial as postoperative pain control for extractions under general anaesthesia.

\title{
Perioperative local anaesthetic in young paediatric patients undergoing extractions under outpatient 'short-case' general anaesthesia. A double-blind randomised controlled trial
}

\author{
K. J. Leong, ${ }^{1}$ G. J. Roberts ${ }^{2}$ and P. F. Ashley ${ }^{3}$
}

Objective To investigate if postoperative pain/discomfort and anxiety experienced by young children who had extractions under general anaesthesia (GA) were affected by perioperative injection techniques of local anaesthetic (LA).

Design A single-centre, double-blind, randomised controlled trial. Setting Conducted in 2002/2003 at the Unit of Paediatric Dentistry, Eastman Dental Hospital, London.

Methods Children, aged 2-6 years scheduled for extractions under $G A$, were randomly assigned to receive either no LA (NLA), infiltration injection (IFL) or intraligamental injection (ITR) perioperatively. All children received analgesic suppositories after induction.

Outcome measures Anxiety was scored using the Venham Picture Scale. Postoperative pain was scored using the Simplified Toddler-Preschooler Postoperative Pain Scale and supplemented with the Modified Pain/Discomfort Scale.

Results Eighteen children received NLA, 17 received IFL and 19 received ITR. Postoperative pain/discomfort and anxiety scores were not significantly different during the period of recovery. On the first night, the intraligamental group had significantly lower pain scores $(p=0.012$ ). Conclusion Postoperative pain/discomfort and anxiety during the period of recovery experienced by young children who had extractions under GA appear not to be affected by perioperative injection techniques of LA. Upon discharge, intraligamental injection appears

\footnotetext{
${ }^{*}$ MClinDent (Paediatric Dentistry) Graduate, ${ }^{2}$ Professor and Consultant in Paediatric Dentistry, ${ }^{3}$ Clinical lecturer in Paediatric Dentistry, Unit of Paediatric Dentistry, Eastman Dental Institute and Hospital, University College London, University of London, 256 Gray's Inn Road, London, WC1X 8LD

*Correspondence to: Dr Kei Joe Leong

Email: kjleong18@hotmail.com
}

Online article number E11

Refereed Paper - accepted 24 January 2007

DOI: 10.1038/bdj.2007.724

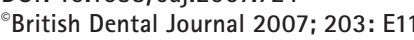

beneficial, as it is probably well tolerated by causing less soft tissue numbness initially and thus, reduces perceived pain/discomfort.

The use of general anaesthesia (GA) for extractions in children is still common. Studies have shown that such procedures are associated with considerable morbidity, where pain was usually the main complaint. ${ }^{1-4}$ Although there are no guidelines, local anaesthetics (LA) containing epinephrine are routinely used perioperatively during extractions under GA for postoperative pain control and reduction of bleeding. Anecdotal observations and studies have suggested that the use of infiltration LA in young children could be distressing, uncomfortable, causes excessive dribbling because of the unfamiliar sensation of numbness and inability to adjust to it, and may also cause inadvertent lip biting., ${ }^{5,6}$ This could also lead to increase in anxiety and higher levels of anxiety are shown to be associated with higher levels of postoperative pain. ${ }^{7}$ One possible method of overcoming this would be to abandon the use of LA. Alternatively, it could be administered using intraligamental injection as there is less associated soft tissue numbness. ${ }^{8}$

There are no blinded, randomised controlled studies comparing perioperative injection techniques of LA in young children having extractions under GA. The objectives of this study were to evaluate if postoperative pain/discomfort and anxiety experienced by young children undergoing extractions under GA with preoperative analgesic suppositories were affected by perioperative injection techniques of LA.

\section{PATIENTS AND METHODS}

\section{Patients}

This was a single-centre, double-blind, randomised controlled trial conducted at the Eastman Dental Hospital, London. Ethical approval was obtained from Eastman Dental Institute/Eastman Dental Hospital Joint Research and Ethics 
Table 1 System of scoring for the Modified Pain/Discomfort Scale

\begin{tabular}{|l|l|}
\hline Item & Score \\
\hline Crying: & \\
Not crying & 0 \\
Responding to comforting & 1 \\
Not responding to comforting & 2 \\
\hline Moving: & \\
None & 0 \\
Restless & 1 \\
Thrashing & 2 \\
\hline Agitation: & \\
Asleep or calm & 0 \\
Mild agitation & 1 \\
Severe agitation/hysterical & 2 \\
\end{tabular}

Table 2 System of scoring for the Simplified Toddler-Preschooler Postoperative Pain Scale

\begin{tabular}{l|l|l|l}
\hline \multirow{2}{*}{ Item } & \multicolumn{2}{l|}{ Score } & 2 \\
\cline { 2 - 4 } & 0 & 1 & \\
\hline $\begin{array}{l}\text { Verbal score } \\
\text { (If child is sleeping, } \\
\text { put 'S'; if child is } \\
\text { unable to tell you } \\
\text { about their pain, } \\
\text { put 'X') }\end{array}$ & 'No pain' & $\begin{array}{l}\text { 'It hurts a } \\
\text { little bit' } \\
\text { 'Small hurt' } \\
\text { 'Ow, ouch' } \\
\text { Moaning, } \\
\text { groaning }\end{array}$ & 'It hurts a lot' \\
'Medium hurt'
\end{tabular}

Table 3 Demographic characteristics for each treatment group

\begin{tabular}{|c|c|c|c|}
\hline Characteristic & $\begin{array}{l}\text { NLA } \\
n=18\end{array}$ & $\begin{array}{l}\text { IFL } \\
\mathrm{n}=17\end{array}$ & $\begin{array}{l}\text { ITR } \\
n=19\end{array}$ \\
\hline $\begin{array}{l}\text { Age (years) } \\
\text { Minimum } \\
\text { Lower quartile } \\
\text { Median } \\
\text { Upper quartile } \\
\text { Maximum }\end{array}$ & $\begin{array}{l}2.6 \\
3.3 \\
4.5 \\
5.0 \\
5.8\end{array}$ & $\begin{array}{l}2.9 \\
4.2 \\
4.7 \\
5.7 \\
5.8\end{array}$ & $\begin{array}{l}2.7 \\
3.6 \\
4.4 \\
5.3 \\
6.0\end{array}$ \\
\hline $\begin{array}{l}\text { Weight }(\mathrm{kg}) \\
\text { Mean } \\
\text { SD }\end{array}$ & $\begin{array}{l}18.0 \\
3.56\end{array}$ & $\begin{array}{l}18.9 \\
2.33\end{array}$ & $\begin{array}{l}18.5 \\
3.40\end{array}$ \\
\hline $\begin{array}{l}\text { Teeth extracted } \\
\text { Minimum } \\
\text { Lower quartile } \\
\text { Median } \\
\text { Upper quartile } \\
\text { Maximum }\end{array}$ & $\begin{array}{l}1 \\
6.8 \\
8.0 \\
10.0 \\
12\end{array}$ & $\begin{array}{l}2 \\
6.5 \\
8.0 \\
11.0 \\
14\end{array}$ & $\begin{array}{l}1 \\
4.0 \\
6.0 \\
8.0 \\
14\end{array}$ \\
\hline $\begin{array}{l}\text { Time to eye opening (min) } \\
\text { Mean } \\
\text { SD }\end{array}$ & $\begin{array}{l}31.0 \\
8.79\end{array}$ & $\begin{array}{l}32.1 \\
8.10\end{array}$ & $\begin{array}{l}34.1 \\
10.56\end{array}$ \\
\hline
\end{tabular}

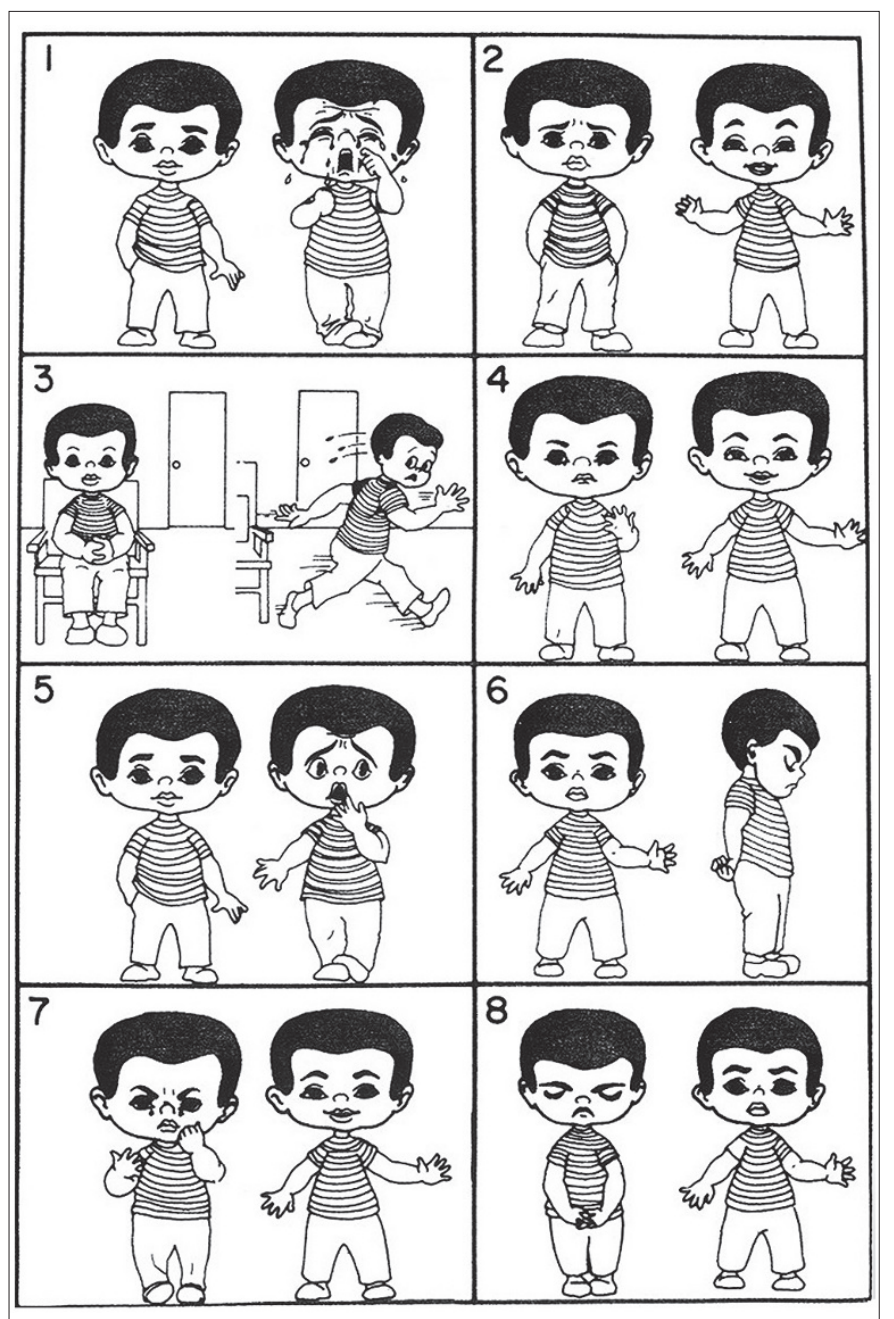

Fig. 1 Venham Picture Scale

Committee, Research and Development, University College London Hospitals. Children aged 2-6 years, ASA physical status I or II, scheduled for extractions of deciduous teeth under outpatient 'short-case' GA were selected. Inclusion criteria included parents/guardians who consented to the study and the use of analgesic suppositories, could communicate well in English and were contactable by telephone for three consecutive nights. Exclusion criteria included children who required extractions of only a few anterior teeth, as these children would be unlikely to receive LA and a laryngeal mask airway due to a short GA, and children who were already in acute pain and had a known medical history of bleeding disorder and hypersensitivity to lidocaine, diclofenac and paracetamol. All children underwent a routine procedure for GA throughout the study.

\section{Preoperative procedures}

Data on patient characteristics and preoperative anxiety scores using the Venham Picture Scale (VPS) were recorded (Fig. 1). The use of VPS has been validated and was reported reliable for use in children aged two years onwards. ${ }^{9,10}$ Children were asked to choose from each of the eight pairs of drawings which boy more accurately reflects their feelings at that time. A score was given every time the more 'anxious' figure was picked. The total score ranges from 0 to 8 and a score of 9 was given if the child refused to use the scale. 


\section{Perioperative procedures}

Upon induction, laryngeal mask airway was placed and analgesic suppositories (diclofenac sodium 1-2 mg kg-1 and paracetamol $20-40 \mathrm{mg} \mathrm{kg}^{-1}$ ) were administered. Anaesthesia was maintained with isoflurane throughout the surgical procedure. Although this regimen is commonly used, the anaesthetists may, based on their judgment on each child, administer only diclofenac sodium or paracetamol and maintain anaesthesia with sevoflurane.

Randomisation was done by means of previously shuffled envelopes containing instructions regarding the injection technique. These were handed to the operators who would be performing the extractions. Lidocaine $2 \%$ with epinephrine 1:80,000 $2.2 \mathrm{ml}$ cartridge (Xylocaine ${ }^{\circledast}$, Astra, UK) was used and the recommended maximum dosage of $4.4 \mathrm{mg} \mathrm{kg}^{-1}$ was not exceeded throughout the study. The three study groups were:

- No perioperative LA (NLA)

- Infiltration injection (IFL). $0.5 \mathrm{ml}$ of LA was administered into each quadrant requiring extractions using a self-aspirating syringe (Aspiject ${ }^{\circledast}$ self-aspirating dental syringe, Denmark) with 30G $21 \mathrm{~mm}$ needles (Carpule $^{\varpi}$, Heraeus Kulzer $)^{5}$

- Intraligamental injection (ITR). $0.2 \mathrm{ml}$ of LA was administered into the mesio-buccal periodontal ligament of each tooth to be extracted using an intraligamental syringe (Citoject ${ }^{\circledR}$, Heraeus Kulzer) with 30G (X-Short) $10 \mathrm{~mm}$ needle (Hypo ${ }^{\circledR}$, Dentsply, USA).

These envelopes were returned to the researcher sealed and were only opened at the end of the study. Both the researcher and the parents/guardians were blind to the technique of perioperative LA.

\section{Postoperative procedures}

The following data were recorded:

i) The duration from commencement of anaesthesia (available from the patients' register in the operating theatre) until consciousness was regained in the recovery room (time to eye opening) ii) Pain and pain/discomfort scores were recorded using the Simplified Toddler-Preschooler Postoperative Pain Scale (STPPPS) and supplemented with the Modified Pain/Discomfort Scale (MPDS):

- MPDS was chosen for its suitability in monitoring during the period of recovery. This was performed at the time of recovery in the recovery room (0 minutes), 15 minutes and 30 minutes. ${ }^{1,11,12}$ Each item was given a score and summed up at each time point of observation (Table 1). The total score ranges from a 0 to 6

- The STPPPS was chosen for its applicability in this age group, validated for use by parents and therefore, suitable for scoring pain at home. This was performed on arrival at the recovery ward (0 minutes), $30 \mathrm{~min}-$ utes, first night, second night and third night. ${ }^{1,13}$ Each item was given a score and summed up at each time point of observation (Table 2). The verbal score of $S$ or $\mathrm{X}$ is regarded as 0 . The total score ranges from 0 to 6 . The duration of 30 minutes was chosen due to fast recovery from such short procedures and these children were usually discharged in about 45 minutes. Upon discharge, parents/guardians were instructed to administer oral analgesics to the child on a p.r.n. basis. Subsequent evaluations were performed through telephone contacts at a pre-arranged time, between 7-8pm

iii) Postoperative anxiety scores was recorded using VPS at about 10-15 minutes after arrival into the recovery ward ${ }^{1}$

iv) Analgesic suppositories and anaesthetic agent (retrieved from the anaesthetic sheet at the end of the study).

\section{Reproducibility}

Inter-rater agreement between two observers was measured using Cohen's weighted kappa. This was performed on eight children, which included 15 paired observations using the STPPPS and 25 paired observations using the MPDS.

\section{Statistical analysis}

Data were processed in SPSS for Windows (Release 11.0.0, Leadtools ${ }^{\bullet}$ 1991-2000, Lead Technologies Inc.). Data were tested for

Table 4 Postoperative pain scores for each treatment group

\begin{tabular}{|c|c|c|c|c|c|c|c|}
\hline & Treatment groups & Minimum & Lower quartile & Median & Upper quartile & Maximum & $P$ value \\
\hline $\begin{array}{l}0 \min \\
(n=54)\end{array}$ & $\begin{array}{l}\text { NLA } \\
\text { IFL } \\
\text { ITR }\end{array}$ & $\begin{array}{l}0 \\
0 \\
0\end{array}$ & $\begin{array}{l}3.8 \\
2.5 \\
2.0\end{array}$ & $\begin{array}{l}4.0 \\
4.0 \\
4.0\end{array}$ & $\begin{array}{l}5.0 \\
4.0 \\
5.0\end{array}$ & $\begin{array}{l}5 \\
5 \\
5\end{array}$ & 0.32 \\
\hline $\begin{array}{l}30 \min \\
(n=54)\end{array}$ & $\begin{array}{l}\text { NLA } \\
\text { IFL } \\
\text { ITR }\end{array}$ & $\begin{array}{l}0 \\
0 \\
0\end{array}$ & $\begin{array}{l}0 \\
0 \\
0\end{array}$ & $\begin{array}{l}2.0 \\
2.0 \\
1.0\end{array}$ & $\begin{array}{l}3.3 \\
4.0 \\
3.0\end{array}$ & $\begin{array}{l}6 \\
4 \\
5\end{array}$ & 0.73 \\
\hline $\begin{array}{l}\text { 1st night } \\
(n=53)\end{array}$ & $\begin{array}{l}\text { NLA } \\
\text { IFL } \\
\text { ITR }\end{array}$ & $\begin{array}{l}0 \\
0 \\
0\end{array}$ & $\begin{array}{l}0 \\
0 \\
0\end{array}$ & $\begin{array}{l}0 \\
0 \\
0\end{array}$ & $\begin{array}{l}0.3 \\
1.0 \\
0\end{array}$ & $\begin{array}{l}1 \\
5 \\
1\end{array}$ & $0.036^{*}$ \\
\hline $\begin{array}{l}\text { 2nd night } \\
(n=52)\end{array}$ & $\begin{array}{l}\text { NLA } \\
\text { IFL } \\
\text { ITR }\end{array}$ & $\begin{array}{l}0 \\
0 \\
0\end{array}$ & $\begin{array}{l}0 \\
0 \\
0\end{array}$ & $\begin{array}{l}0 \\
0 \\
0\end{array}$ & $\begin{array}{l}0.5 \\
0 \\
0\end{array}$ & $\begin{array}{l}3 \\
6 \\
3\end{array}$ & 0.64 \\
\hline $\begin{array}{l}\text { 3rd night } \\
(n=52)\end{array}$ & $\begin{array}{l}\text { NLA } \\
\text { IFL } \\
\text { ITR }\end{array}$ & $\begin{array}{l}0 \\
0 \\
0\end{array}$ & $\begin{array}{l}0 \\
0 \\
0\end{array}$ & $\begin{array}{l}0 \\
0 \\
0\end{array}$ & $\begin{array}{l}0.5 \\
0 \\
0\end{array}$ & $\begin{array}{l}2 \\
1 \\
2\end{array}$ & 0.30 \\
\hline
\end{tabular}


Table 5 Postoperative pain/discomfort scores for each treatment group

\begin{tabular}{|c|c|c|c|c|c|c|c|}
\hline & Treatment groups & Minimum & Lower quartile & Median & Upper quartile & Maximum & $P$ value \\
\hline $\begin{array}{l}0 \min \\
(n=54)\end{array}$ & $\begin{array}{l}\text { NLA } \\
\text { IFL } \\
\text { ITR }\end{array}$ & $\begin{array}{l}0 \\
0 \\
0\end{array}$ & $\begin{array}{l}1.8 \\
1.0 \\
0\end{array}$ & $\begin{array}{l}2.5 \\
4.0 \\
4.0\end{array}$ & $\begin{array}{l}4.5 \\
4.0 \\
4.0\end{array}$ & $\begin{array}{l}6 \\
5 \\
6\end{array}$ & 0.96 \\
\hline $\begin{array}{l}15 \min \\
(n=54)\end{array}$ & $\begin{array}{l}\text { NLA } \\
\text { IFL } \\
\text { ITR }\end{array}$ & $\begin{array}{l}0 \\
0 \\
0\end{array}$ & $\begin{array}{l}0 \\
0 \\
0\end{array}$ & $\begin{array}{l}2.0 \\
1.0 \\
0\end{array}$ & $\begin{array}{l}4.0 \\
1.0 \\
3.0\end{array}$ & $\begin{array}{l}6 \\
4 \\
6\end{array}$ & 0.15 \\
\hline $\begin{array}{l}30 \min \\
(n=54)\end{array}$ & $\begin{array}{l}\text { NLA } \\
\text { IFL } \\
\text { ITR }\end{array}$ & $\begin{array}{l}0 \\
0 \\
0\end{array}$ & $\begin{array}{l}0 \\
0 \\
0\end{array}$ & $\begin{array}{l}0.5 \\
0 \\
0\end{array}$ & $\begin{array}{l}1.0 \\
1.0 \\
1.0\end{array}$ & $\begin{array}{l}6 \\
2 \\
6\end{array}$ & 0.49 \\
\hline
\end{tabular}

Table 6 Preoperative and postoperative anxiety scores for each treatment group

\begin{tabular}{|c|c|c|c|c|c|c|c|c|}
\hline Treatment group & $n$ & & Minimum & Lower quartile & Median & Upper quartile & Maximum & $P$ value \\
\hline NLA & 17 & $\begin{array}{l}\text { Preoperative score } \\
\text { Postoperative score }\end{array}$ & $\begin{array}{l}0 \\
2\end{array}$ & $\begin{array}{l}0.5 \\
4.0\end{array}$ & $\begin{array}{l}3.0 \\
7.0\end{array}$ & $\begin{array}{l}7.0 \\
9.0\end{array}$ & $\begin{array}{l}9 \\
9\end{array}$ & $0.003^{*}$ \\
\hline IFL & 17 & $\begin{array}{l}\text { Preoperative score } \\
\text { Postoperative score }\end{array}$ & $\begin{array}{l}0 \\
0\end{array}$ & $\begin{array}{l}0 \\
1.5\end{array}$ & $\begin{array}{l}2.0 \\
5.0\end{array}$ & $\begin{array}{l}5.5 \\
9.0\end{array}$ & $\begin{array}{l}9 \\
9\end{array}$ & $0.013^{*}$ \\
\hline ITR & 18 & $\begin{array}{l}\text { Preoperative score } \\
\text { Postoperative score }\end{array}$ & $\begin{array}{l}0 \\
0\end{array}$ & $\begin{array}{l}1.0 \\
5.3\end{array}$ & $\begin{array}{l}2.5 \\
9.0\end{array}$ & $\begin{array}{l}5.8 \\
9.0\end{array}$ & $\begin{array}{l}9 \\
9\end{array}$ & $0.020^{*}$ \\
\hline Total & 52 & & & & & & & \\
\hline
\end{tabular}

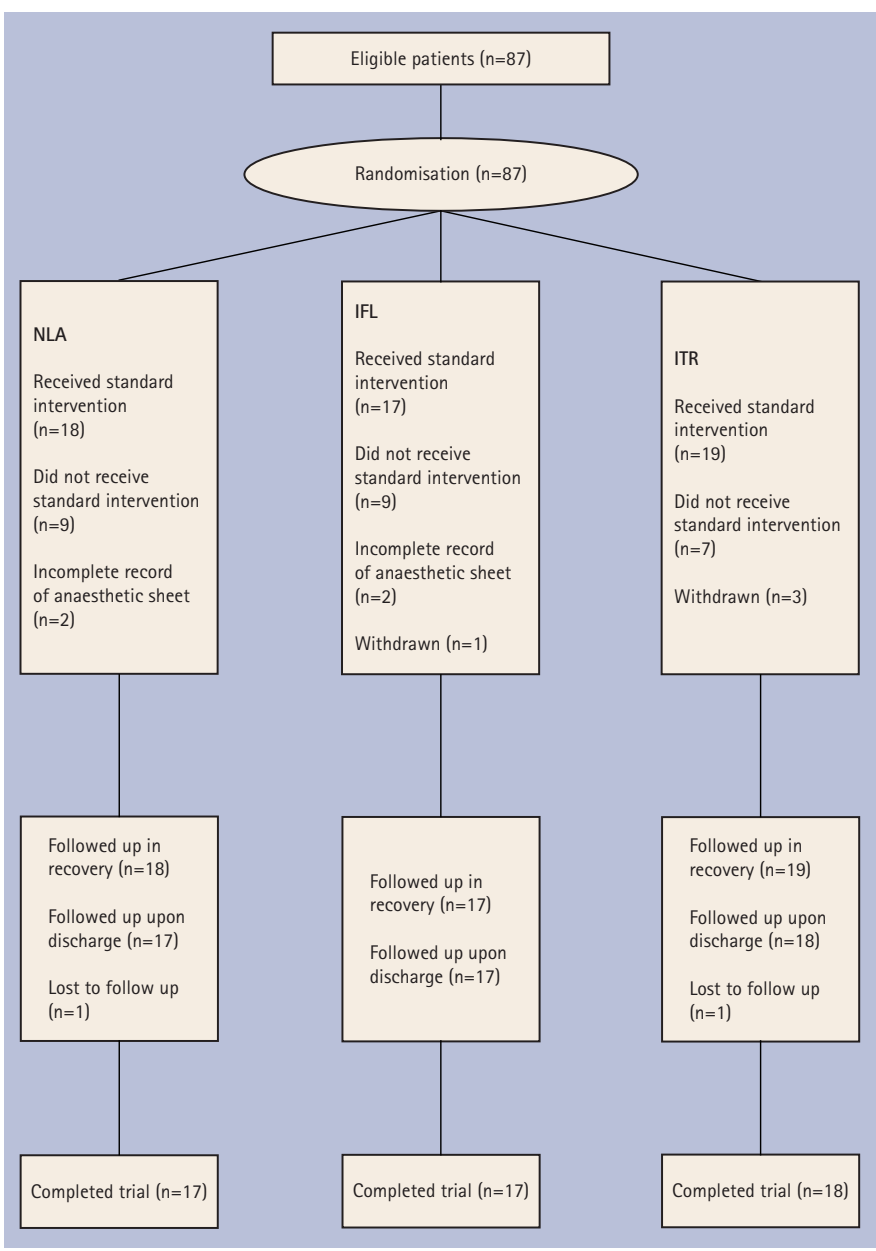

Fig. 2 Disposition of patients normality using the Shapiro-Wilk statistic and reported as mean and SD if normality was assumed, or median with inter-quartile range (IQR) and range if normality was not assumed. Data on patient characteristics were compared using ANOVA if the data were normally distributed while Kruskal-Wallis test was applied for non-normally distributed data. The main outcome variables - pain, pain/discomfort and anxiety scores showed significant deviations from a normal distribution and thus Kruskal-Wallis, Mann-Whitney U test and Wilcoxon signedrank test (preoperative and postoperative anxiety scores) were used to test for evidence of significant differences. Correlation relationships between these main outcome variables were analysed using Spearman's rank-order correlation..$^{14} \mathrm{~A}$ p-value less than 0.05 was considered statistically significant for all the tests performed. No preliminary data was available for a power calculation and we determined that a study with 18 subjects per group would detect a shift of 0.93 standard deviations with power $80 \%$ at the conventional 5\% alpha level.

\section{RESULTS}

Of the 87 randomised children, we analysed data from 54 children as all of these received both diclofenac sodium and paracetamol suppositories and isoflurane as the anaesthetic agent. Twenty-five children received a different analgesic suppository and anaesthetic agent, four withdrew from the study and another four had an incomplete record of their anaesthetic sheet. Of the 54 children, 18 received NLA, 17 received IFL and 19 received ITR. The three groups were similar in age, weight, number of teeth extracted and time to eye opening (Table 3). Figure 2 shows a flow diagram illustrating the disposition of children in the study. 
A reduction of pain scores was observed in all the groups from 0 minutes to the third night postoperatively, with significant differences among the three groups only on the first night $(p=0.036)$ (Table 4$)$. Further analysis showed that the ITR group had significantly lower pain scores compared to IFL group ( $p=0.012$ ). Reduction of pain/discomfort scores was also observed in the three groups with no significant differences at any time point of observation (Table 5).

Postoperative anxiety scores were significantly higher compared to preoperative anxiety scores in each group (Table 6). Further analysis showed that postoperative anxiety scores among the three groups were not significantly different ( $p=$ 0.23). There were also no significant correlations between the main outcome variables in both NLA and IFL groups. In the ITR group (Table 7), although preoperative anxiety scores were also not correlated with pain and pain/discomfort scores, postoperative anxiety scores showed significant correlation with pain/discomfort scores at 0 minutes $(p=0.002)$ and $15 \mathrm{~min}$ utes $(p=0.023)$, and pain scores at 0 minutes $(p=0.006)$. Two children were excluded, as they were unable to comprehend the use of VPS.

The weighted kappa values ranged from 0.77-0.95 for the items in STPPPS and 0.71-0.73 for the items in MPDS. There appeared to be 'good' to 'very good' agreement between both observers in assessing pain and pain/discomfort scores.

\section{DISCUSSION}

The results obtained from the 54 children seemed to indicate that the use of perioperative LA in young children undergoing extractions under GA is of little benefit during the period of recovery. It appeared that pain, pain/discomfort and anxiety scores were not significantly different among the three groups at any time point of observation during the period of recovery. The fact that there were no significant differences in postoperative pain between the use of perioperative LA and no LA was concordant with a previous study. ${ }^{15}$ The results of this study, however, did not coincide with another study, in which children who had perioperative infiltration injection of LA appeared to be more distressed. ${ }^{5}$

The ITR group did not show significantly lower pain and pain/discomfort scores during the period of recovery as predicted. This could result from administering only $0.2 \mathrm{ml}$ of LA for each tooth. There are no publications regarding the use of intraligamental injection for multiple extractions under GA. The intraligamental injection technique described by most authorities is mainly meant for treatment on a single tooth and requires mesial and distal injection for multi-rooted teeth. We wanted to investigate the possibility of using this technique for multiple extractions of deciduous teeth including a full mouth clearance. If $0.2 \mathrm{ml}$ were administered for single rooted teeth and $0.4 \mathrm{ml}(0.2 \mathrm{ml}$ mesially and $0.2 \mathrm{ml}$ distally) for multirooted teeth, the minimum weight for a full mouth clearance (20 teeth) would be $25.5 \mathrm{~kg}$, which is above the average weight for children aged below six years.

The insignificant differences in pain and pain/discomfort scores during the period of recovery could also be caused by the administration of analgesic suppositories. Although the IFL and ITR would clinically have longer treatment time, the time to eye opening was not significantly different between the three groups, with an overall mean (SD) of 32.4 (9.17)

\begin{tabular}{|c|c|c|c|}
\hline & & $\begin{array}{l}\text { Anxiety } \\
\text { preoperative }\end{array}$ & $\begin{array}{l}\text { Anxiety } \\
\text { postoperative }\end{array}$ \\
\hline \multirow{3}{*}{$\begin{array}{l}\text { Anxiety } \\
\text { preoperative }\end{array}$} & $\begin{array}{l}\text { Correlation } \\
\text { coefficient }\end{array}$ & 1.000 & 0.097 \\
\hline & Sig. (2-tailed) & & 0.70 \\
\hline & $n$ & 18 & 18 \\
\hline \multirow{3}{*}{$\begin{array}{l}\text { Anxiety } \\
\text { post-operative }\end{array}$} & $\begin{array}{l}\text { Correlation } \\
\text { coefficient }\end{array}$ & 0.097 & 1.000 \\
\hline & Sig. (2-tailed) & 0.70 & \\
\hline & $n$ & 18 & 18 \\
\hline \multirow{3}{*}{$\begin{array}{l}\text { Pain/discomfort } \\
0 \mathrm{~min}\end{array}$} & $\begin{array}{l}\text { Correlation } \\
\text { coefficient }\end{array}$ & 0.168 & 0.687 \\
\hline & Sig. (2-tailed) & 0.51 & $0.002^{*}$ \\
\hline & $n$ & 18 & 18 \\
\hline \multirow{3}{*}{$\begin{array}{l}\text { Pain/discomfort } \\
15 \mathrm{~min}\end{array}$} & $\begin{array}{l}\text { Correlation } \\
\text { coefficient }\end{array}$ & 0.357 & 0.532 \\
\hline & Sig. (2-tailed) & 0.15 & $0.023^{*}$ \\
\hline & $n$ & 18 & 18 \\
\hline \multirow{3}{*}{$\begin{array}{l}\text { Pain/discomfort } \\
30 \mathrm{~min}\end{array}$} & $\begin{array}{l}\text { Correlation } \\
\text { coefficient }\end{array}$ & 0.098 & 0.365 \\
\hline & Sig. (2-tailed) & 0.70 & 0.14 \\
\hline & $n$ & 18 & 18 \\
\hline \multirow{3}{*}{$\begin{array}{l}\text { Pain/discomfort } \\
45 \mathrm{~min}\end{array}$} & $\begin{array}{l}\text { Correlation } \\
\text { coefficient }\end{array}$ & -0.043 & 0.342 \\
\hline & Sig. (2-tailed) & 0.88 & 0.21 \\
\hline & $n$ & 15 & 15 \\
\hline \multirow{3}{*}{ Pain 0 min } & $\begin{array}{l}\text { Correlation } \\
\text { coefficient }\end{array}$ & 0.031 & 0.623 \\
\hline & Sig. (2-tailed) & 0.90 & $0.006^{*}$ \\
\hline & $n$ & 18 & 18 \\
\hline \multirow{3}{*}{ Pain $30 \mathrm{~min}$} & $\begin{array}{l}\text { Correlation } \\
\text { coefficient }\end{array}$ & 0.190 & 0.443 \\
\hline & Sig. (2-tailed) & 0.45 & 0.065 \\
\hline & $n$ & 18 & 18 \\
\hline \multirow{3}{*}{ Pain 1st night } & $\begin{array}{l}\text { Correlation } \\
\text { coefficient }\end{array}$ & -0.078 & 0.158 \\
\hline & Sig. (2-tailed) & 0.77 & 0.54 \\
\hline & $n$ & 17 & 17 \\
\hline \multirow{3}{*}{ Pain 2nd night } & $\begin{array}{l}\text { Correlation } \\
\text { coefficient }\end{array}$ & -0.078 & 0.158 \\
\hline & Sig. (2-tailed) & 0.77 & 0.54 \\
\hline & $n$ & 17 & 17 \\
\hline \multirow{3}{*}{ Pain 3rd night } & $\begin{array}{l}\text { Correlation } \\
\text { coefficient }\end{array}$ & -0.078 & -0.444 \\
\hline & Sig. (2-tailed) & 0.77 & 0.074 \\
\hline & $n$ & 17 & 17 \\
\hline
\end{tabular}


minutes. As suppository diclofenac sodium would reach peak plasma concentrations in about 30 minutes, ${ }^{11,16}$ faster than paracetamol, the insignificant differences in pain and pain/ discomfort scores during the period of recovery could be caused by the use of this medication.

Apart from the use of analgesic suppositories, the insignificant differences in pain and pain/discomfort scores during the period of recovery could be caused by these children, due to their young age, being disorientated, confused and agitated on awakening in a different environment. Agitation on emergence from anaesthesia has been shown to be associated with the use of isoflurane as an anaesthetic agent. ${ }^{17}$

The fact that these children were disorientated, confused and agitated could also explain the significant increase in postoperative anxiety scores in all the study groups. The present results did not show any significant differences in postoperative anxiety scores and thus, perioperative LA techniques might not be a contributing factor. The findings of this study support previous research in which patients' preoperative anxiety did not relate directly to their postoperative pain. ${ }^{7}$ They were probably unaware of how much discomfort to expect after surgery, possibly from being reassured by their parents that they would not feel pain as they will be 'asleep' throughout the procedure. Although a previous report suggested that postoperative anxiety is positively related to postoperative pain, ${ }^{7}$ this was not generally shown to be the case in this study, except for the ITR group, which could be just coincidental. The causes of these findings could probably be multi-factorial, as explained earlier, a mixture of disorientation, confusion and agitation and due to young age.

Upon discharge, the ITR group had significantly lower pain scores on the first night postoperatively compared to the IFL group ( $p=0.012)$. It seemed that the use of intraligamental injection could be more advantageous as the after-effect of lesser soft tissue numbness initially could somehow be better tolerated with reduced perceived pain/discomfort and thus, showed more favourable outcomes later.

The results of this study raised important issues regarding the use and benefits of perioperative LA for extractions under GA. It has been reported that the sole use of anaesthetic agent is unable to suppress haemodynamic reactions (blood pressure and heart rate) or cardiac arrhythmias arising from painful surgical stimuli. ${ }^{18,19}$ As studies have shown that the use of perioperative LA in combination with GA could reduce these responses to surgical stimulation, ${ }^{18,20}$ it seemed reasonable to continue this practice.

\section{CONCLUSION}

Evidence from this study seemed to suggest that postoperative pain/discomfort and anxiety experienced during the period of recovery by young children who had extractions under outpatient 'short-case' GA with preoperative analgesic suppositories, were not affected by perioperative injection techniques and the use of LA. Upon discharge, however, children who received perioperative intraligamental injection of LA had significantly lower pain scores on the first night postoperatively.

The authors would like to thank the anaesthetic nurses, anaesthetists, consultants and the senior house officers in paediatric dentistry, Eastman Dental Hospital, for their technical assistance during this study.

1. Atan S, Ashley P, Gilthorpe M S, Scheer B, Mason C, Roberts G. Morbidity following dental treatment under intubation general anesthesia in a day-stay unit. Int J Paediatr Dent 2004; 14: 9-16.

2. Bridgman $C M$, Ashby $D$, Holloway P J. An investigation of the effects on children of tooth extraction under general anaesthesia in general dental practice. Br Dent J 1999; 186: 245-247.

3. Fung D E, Cooper D J, Barnard K M, Smith P B. Pain reported by children after dental extractions under general anaesthesia: a pilot study. Int J Paediatr Dent 1993: $\mathbf{3}: 23-28$

4. Roelofse J A, Payne K A. Oral tramadol: analgesic efficacy in children following multiple dental extractions. Eur J Anaesthesio/ 1999; 16: 441-447.

5. Al-Bahlani S, Sherriff A, Crawford P J M. Tooth extraction, bleeding and pain control. J R Coll Surg Edinb 2001; 46: 261-264

6. Andrzejowski J, Lamb L. The effect of swabs soaked in bupivacaine and epinephrine for pain relief following simple dental extractions in children. Anaesthesia 2002; 57: 266-283

7. LaMontagne L L, Hepworth J T, Salisbury M H. Anxiety and postoperative pain in children who undergo major orthopedic surgery. Appl Nurs Res 2001; 14: $119-124$.

8. Robinson P D, Pitt Ford T R, McDonald F. Local anaesthesia in dentistry. 1st ed. pp 1-14. Oxford: Wright, 2000.

9. Aartman I H, van Everdingen T, Hoogstraten J, Schuurs A H. Self-report measurements of dental anxiety and fear in children: a critical assessment. ASDC J Dent Child 1998; 65: 252-230.

10. Venham $L L$, Gaulin-Kremer E. A self report measure of situational anxiety for young children. Pediatr Dent 1979; 1: 91-96.

11. Littlejohn I J, Tarling M M, Flynn P J, Ordman A J, Aiken A. Post-operative pain relief in children following extraction of carious deciduous teeth under general anaesthesia: a comparison of nalbuphine and diclofenac. Eur J Anaesthesiol 1996; 13: 359-363.

12. Viitane N H, Baer G, Annila P. Recovery characteristics of sevoflurane or halothane for day-case anaesthesia in children aged 1-3 years. Acta Anaesthesiol Scand 2000; 44: 101-106.

13. Morgan J, Peden V, Bhaskar K, Vater M, Choonara I. Assessment of pain by parents in young children following surgery. Paed Anaesth 2001; 11: 449-452.

14. Lang T A, Secic M. How to report statistics in medicine. Annotated guidelines for authors, editors, and reviewers. pp 43-104. Philadelphia: American College of Physicians, 1997.

15. Jurgens S, Warwick R S, Inglehearn P J, Gooneratne D S. Pain relief for paediatric dental chair anaesthesia: current practice in a community dental clinic. Int J Paediatr Dent 2003: 13: 93-97.

16. Idkaidek N M, Amidon G L, Smith D E, Najib N M, Hassan M M. Determination of the population pharmacokinetic parameters of sustained-release and entericcoated oral formulations, and the suppository formulation of diclofenac sodium by simultaneous data fitting using NONMEM. Biopharm Drug Dispos 1998; 19: $169-174$

17. Mendel P, Fredman B, White P F. Alfentanil suppresses coughing and agitation during emergence from isoflurane anesthesia. J Clin Anesth 1995; 7: 114-118.

18. Wilson I H, Richmond M N, Strike P W. Regional analgesia with bupivacaine in dental anaesthesia. Br J Anaesth 1986; 58: 401-405.

19. Zbinden A M, Peterson-Felix S, Thomson D A. Anesthetic depth defined using multiple noxious stimuli during isoflurane/oxygen anesthesia. II. Hemodynamic responses. Anesthesiology 1994; 80: 261-267.

20. Rashad A, El-Attar A. Cardiac dysrhythmias during oral surgery: effect of combined local and general anaesthesia. Br J Oral Maxillofac Surg 1990; 28: 102-104. 